\title{
Isto é meu corpo" (que é dado por vós): o grotesco, a tortura e o sacrifício no romance agá, de Hermilo Borba Filho"
}

\author{
Luiz Roberto Leite Farias ${ }^{1}$
}

Resumo: Neste artigo, baseado no romance Agá, de Hermilo Borba Filho, propomos um olhar crítico sobre os corpos dos torturados, que os confunde com o corpo deformado de Cristo, além de que essa analogia também torna o chão da cela da prisão uma verdadeira mesa de dissecação. Assim, o olhar sobre os corpos dos torturados confunde-se com o olhar de um anatomista que mapeia a ação do poder sobre os corpos como forma de erigir um memorial da tortura, um testemunho que preserve a memória dos que perderam a vida nos porões da repressão no Brasil.

Palavras-chave: Hermilo Borba Filho. Crítica literária. Grotesco. Tortura.

Abstract: In this article, based on the novel Agá, by Hermilo Borba Filho, we propose a critical view over the bodies of the tortured, which confounds it with the deformed body of Christ, besides the fact that the analogy also turns the floor of the jail cell into a real dissection table. Thereby, the look over the bodies of the tortured intertwines with the anatomist's attentive gaze that maps the action of power over the bodies as a way of erecting a memorial of torture, a testimony that preserves the memory of those who lost their lives in the holds of the repression in Brazil.

Keywords: Hermilo Borba Filho. Literary Criticism. Grotesque. Torture.

Résumé: Dans cet article, basé sur le roman Agá de l'auteur Hermilo Borba Filho, nous proposons un regard critique sur les corps des torturés, qui sont confondus avec le corps déformé du Christ, poussant l'analogie à transformer également le sol de la cellule de prison en table de dissection. Le regard porté sur les corps des torturés se confond ainsi avec celui d'un anatomiste qui cartographie l'action du pouvoir sur ces corps comme une forme d'ériger un mémorial de la torture, un témoignage qui préserve la mémoire de ceux qui perdirent la vie dans les sous-sols de la répression brésilienne.

Mots-clés: Hermilo Borba Filho. Critique Littéraire. Grotesque. Torture.

1 Mestre em Teoria da Literatura pelo Programa de Pós-Graduação em Letras da UFPE (PPGL/UFPE) e Doutorando pelo mesmo PPGL/UFPE.

Este artigo está licenciado sob forma de uma licença Creative Commons Atribuição 4.0 Internacional,

que permite uso irrestrito, distribuição e reprodução em qualquer meio, desde que a publicação

original seja corretamente citada. https://creativecommons.org/licenses/by/4.0/deed.pt BR.

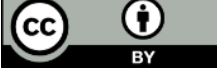

(1) 
Romance publicado em 1974, em meio a um regime ditatorial, Agá é uma narrativa atravessada pela tortura e a execução dos que se rebelam. O corpo humano é esmagado e despedaçado de forma grotesca, tudo descrito em minúcias, em um verdadeiro manual de suplício da carne. Mas, apesar desse aspecto negativo, em que se vê o ser humano sendo destruído por Estados totalitários, Agá também é permeado por uma postura de resistência, em que os perseguidos não se dobram e oferecem seus corpos em sacrifício. O corpo pode ser destruído, mas, assim como na figura do sacrifício de Cristo, que permeia, especialmente o capítulo Eu, padre, o sofrimento da carne transcende a materialidade da dor, sem falar que o papel da literatura de Hermilo Borba Filho é justamente este: o de ser um memorial da tortura, ou seja, uma narrativa que não permita que os abusos e assassinatos praticados pelo poder sejam esquecidos.

$\mathrm{Na}$ intersecção da tortura dos prisioneiros políticos com o martírio de Cristo, é possível, também, abrir uma reflexão sobre a relação entre os corpos quebrantados dos torturados, e a deformação, que poderíamos chamar de grotesca, na representação do corpo de Cristo, reforçando o pensamento de Mikhail Bakhtin sobre o rebaixamento do sagrado:

O rebaixamento é enfim o princípio artístico essencial do realismo grotesco: todas as coisas sagradas e elevadas aí são reinterpretadas no plano material e corporal. Já falamos da gangorra grotesca que funde o céu e a terra no seu vertiginoso movimento; a ênfase, contudo se coloca menos na subida que na queda, é o céu que desce à terra e não o inverso (BAKHTIN, 2013, p. 325).

A figura de Cristo, então, pode ser rebaixada e reinterpretada no plano material, o que, por outro lado, funde essas mesmas coisas materiais e corporais com o sagrado e o sublime. Além disso, o chão dos 
porões da ditadura, que abriga os corpos despedaçados pela força bruta de um sistema, também põe o romance Agá no âmbito da arte moderna, desde Lautréamont até o Séc. XX, com suas mesas de dissecação, revelando o homem cada vez mais complexo e fragmentado, tão presente nessa obra de Hermilo Borba Filho. Por fim, as incursões na anatomia do corpo torturado abrem caminho para uma possível conversão do olhar em discurso literário, em um memorial da estupidez humana.

No princípio do romance, o protagonista Agá, como um herói cômico moderno, apresenta como se dá a gênese do seu tipo, ou seja, ele é um herói de ocasião. Para ele, o herói é feito no momento em que é cobrada sua participação nos eventos mais dramáticos, e não por um valor moral intrínseco à sua personalidade. E ele, para tentar demonstrar alguma coragem que o qualifique, desdenha dos ditadores, mas já lembrando com temor dos métodos de suplício para os que se rebelam, enumerando parte do rosário de torturas que desfilam pelas páginas do romance:

Foi farda me cago. Foi bala, me cago. Foi faca, me cago. Tenho um profundo respeito pela eletricidade, já que ela me dá desde o gelo para um Martini bem seco às queimaduras na minha querida glande nestes tempos onde não se deve pensar quanto mais escrever ou falar. Mas de repente me convenço que, à minha maneira, sou um Agá como foi meu bisavô e cago para todos os ditadores. Na hora, veremos. Não será pior a traição da mulher a quem se ama do que um choque elétrico? Muito pior a traição ao semelhante do que o pau-de-arara? Muito pior ainda a sufocação do pensamento, em palavras orais e escritas, em atos, do que o mergulho num barril de óleo de automóvel? Ninguém sabe quando tem ou não vocação para mártir. Nunca se faz um mártir por antecipação (BORBA FILHO, 1974, p. 19).

Dessa forma de ação do herói, que mistura o medo e a valentia momentânea, os diversos narradores Agás - como um ator que troca 
suas máscaras - e os personagens que estão ao seu redor irão sobrevivendo e resistindo. Isso sem falar na presença dos personagens históricos e seus martírios relatados na história em quadrinhos, na parte central do romance, na qual seus corpos são esquartejados e despojados de maneira costumeira: puxados por cavalos, pelas ruas das cidades. Além disso, destaca-se, nessa passagem, o ponto relevante de que Agá geralmente não tem vocação para engajar seu corpo na luta, de bom grado, embora, às vezes, o faça ("Na hora veremos"). Deixa entrever, porém, que ele pode participar da resistência através da escrita, sem dar espaço para "a sufocação do pensamento, em palavras orais e escritas", o que de fato ele faz, como forma de memorial da tortura: escreve um diário, no episódio do capítulo Eu, Padre.

Assim, ao surgir o protagonista Agá na pele de um padre, e na véspera de um golpe militar, a narrativa passa de momentos de memória e contemplação espiritual para, subitamente, entrar nos porões da tortura e no inferno de suplícios do ser humano. O Agá padre parece ser a faceta, dentre suas várias personificações, mais revestida de humildade e compreensão com a dor humana. Ele se apresenta como um homem já envelhecido e viúvo, e que busca alguma paz em um refúgio espiritual, em um mosteiro no alto da cidade de Olinda. Devido a esse seu caráter compassivo, neste capítulo, e embora tenha sido torturado apenas de forma psicológica, o que já não é pouco, ele tem a oportunidade de se irmanar com os que são torturados por um Estado autoritário e impiedoso para com os que se rebelam e resistem.

Dentro dos porões da repressão, o sacrifício dos torturados realiza diversas analogias: em primeiro, o sofrimento dos presos assemelha-se ao martírio dos cristãos, colocando o sofrimento dos presos políticos no mesmo patamar das perseguições aos primeiros seguidores de Cristo. 
Dessa forma, podemos ver nas notas do diário do padre - em forma de mise en abyme - inserido na fábula do romance:

Outubro: Fui interrogado vezes sem conta e, de cada vez, em pé, durante horas e mais horas. Chamavam-me de "o padre comunista" e eu sabia que não estava só porque se referiam a outros "padres comunistas". Fui ameaçado, mas não torturado, isto é, torturado fisicamente. De cada vez que era chamado precisava lançar mão de todas as minhas forças para lutar contra o medo físico que de mim se apossava, mas graças a isto cheguei a compreender, pela primeira vez, o sacrifício dos primeiros cristãos, pois na verdade consegui separar o corpo da alma. Os dois jamais chegaram a tremer juntos (BORBA FILHO, 1974, p. 57).

Em segundo lugar, e o que é mais preponderante no capítulo $E u$, Padre é o desejo de atualizar o cristianismo para o cenário de convulsão social na América Latina, nos anos 1960. Se pudermos contextualizar o romance Agá com o momento em que foi escrito, e no qual se desenrola o enredo, Hermilo Borba Filho insere este capítulo na discussão que antecede ao dia em que os militares tomam o poder, em 31 de março de 1964. O texto, de certa forma, autoriza a isso, tal a quantidade de marcas históricas - datas relevantes - e indicações topográficas da cidade do Recife e de Olinda.

Portanto, por Agá ser padre, o que de antemão se sobressai é a questão do engajamento da Igreja Católica e dos que se dizem cristãos na defesa dos que são perseguidos e oprimidos, o que toma grande impulso com a chegada na cidade de um "Senhor Arcebispo Dom Heitor", padre militante e destemido. Borba Filho, mantendo um traço de outros romances seus, de inserir personagens históricos com pequenas mudanças no nome próprio, traz, para o centro da discussão, a vida do Arcebispo de Olinda e Recife, Dom Hélder, e seu despertar da 
Igreja para se posicionar em defesa dos oprimidos, naquele momento conturbado e violento da história do Brasil.

Na véspera do golpe militar, o Agá padre faz um sermão em que ele cita o profeta Amós e também a brutalidade sofrida por um estudante baleado na coluna (o que poderia remeter ao atentado a Candido Pinto, presidente do DCE da UFPE, em 1969, e que o deixou paraplégico). Logo após à missa, ele recebe a visita de industriais que frequentam sua igreja, protestando quanto ao teor inconformado do padre, segundo eles, “incitando os paroquianos à revolta" (BORBA FILHO, 1974, p. 51). O padre então escreve em seu diário, criticando o cristianismo domesticado e pacífico da burguesia:

Ouvi-os calmamente e lembrei-lhes que Cristo estava do lado dos oprimidos. Isto, para eles, não funciona. Preferem ter o seu Jesus de coração colorido e preferem ainda mais pensar que as palavras do Salvador foram apenas dirigidas ao povo de Sua época, sem caráter de permanência em relação a qualquer forma de opressão. O fato é que encaram Cristo como uma figura do passado (BORBA FILHO, 1974, p. 51).

Após o golpe militar, esse seu engajamento acaba por levá-lo, como preso político, para os porões da repressão da ditadura. Nesse calabouço da tortura, a narrativa assume a ambiência mais macabra e grotesca do romance, tal o caráter infernal e inumano que envolve o local. O corpo humano também sofre as agruras que poderiam frequentar qualquer quadro de Hieronymus Bosch ou Pieter Brughel e suas representações do inferno:

Durante toda a madrugada eu ouvia gritos, estranhando que gargantas emitissem aqueles sons, às vezes semelhantes a uma sirene, outras, por exemplo, às dores do parto, mas quase sempre iguais aos de um cão a quem se arrancassem os escrotos com uma torquês (BORBA FILHO, 1974, p. 59). 
Nesse tipo de narrativa grotesca, percebe-se como, além da ambiência infernal, a imagem humana funde-se com a de outros animais, no caso, a de um cão, como fruto da força diabólica da tortura, sem falar da rudeza da linguagem, adequada à situação descrita. Além disso, a fusão grotesca também se dá na imagem - mais adiante - de um homem torturado, quando assume o estado de feto, como resultado dos espancamentos, pelas inúmeras sevícias que trituram sua carne e seus ossos: o torturado é homem e feto, simultaneamente, unidos no desamparo, início e fim da forma humana.

Essa fusão de homem e feto acontece quando as memórias do padre vêm à tona, o que se confunde com personagens de outros romances de Hermilo Borba Filho: "Sentei-me na cama, olhei para a figura dobrada mais parecendo um feto no útero, lembrança das minhas antigas gravuras coloridas do curso de medicina” (BORBA FILHO, 1974, p. 59). Essa coincidência do passado do padre com a vida de Hermilo Borba Filho (ele foi estudante de medicina), ou o passado de Hermilo, protagonista da tetralogia Um cavalheiro da segunda decadência, lança dúvidas se o romance Agá não seria mais um de cunho autobiográfico, como Borba Filho havia afirmado que não o seria, embora tenha dito isso de maneira ambígua.

Sobre esse aspecto autobiográfico, Sônia Maria van Dijck Lima, em Gênese de uma poética da transtextualidade (1993), comenta algumas entrevistas dadas por Borba Filho, em que ele oscilava entre dizer que a tetralogia Um cavalheiro da segunda decadência havia sido a última vez que falara de si mesmo ("Minha catarse já foi feita, minha confissão executada, minhas penas cumpridas".), e outro depoimento, em que 
afirmara que Agá seria o último autobiográfico ("Com este livro, deixo definitivamente de falar de mim”.). Diz a autora: “Como podemos, então, procurar compreender Agá? Os críticos apontaram sua forma inusitada de composição. O escritor, após incluí-lo na temática autobiográfica, ressaltou que não se trata de material de tal espécie de livro" (LIMA, 1993, p. 38-39).

Mas independentemente de o romance ser autobiográfico ou não, o passado médico do personagem permite que se recorra a alguns motivos não só caros ao autor pernambucano, mas também ao grotesco e ao surrealismo - a mesa de dissecação e as aulas de anatomia inserindo, assim, o romance de Hermilo Borba Filho numa categoria marcadamente modernista. Um bom exemplo, e que contextualiza as memórias do padre, acontece quando o Hermilo, narrador de A Porteira do mundo, em seu tempo de estudante na Escola de Medicina do Recife, trava um encontro de certa forma tragicômico - e bastante grotesco com o ridículo e a fraqueza da existência humana, ao assistir às aulas de um professor sádico, que abusava dos corpos dos cadáveres. Diz esse Hermilo sobre a sala de aulas de anatomia:

Às sete da manhã começava a aula de anatomia, no anfiteatro frio, os cadáveres boiando em grandes tinas de formol ou alinhados em prateleiras geladas, o primeiro que cortei me valeu passar uma semana comendo bolacha de faca e garfo. [...] na mesa de cimento a barriga da velha gorda, cortada, deixava ver a gordura que me lembrava enxúndia de galinha; noutra mesa as moscas pousavam no pênis descomunal do negro de boca aberta deixando ver os dentes claros; esqueletos pendurados agitavam-se levemente numa dança triste, irreversíveis; e por toda a parte o cheiro de formol e da podridão, entranhando-se em minha roupa, obrigando-me a cortar as unhas até o sabugo [...] (BORBA FILHO, 1994, p. 168) 
Como se vê, essa sala de aula e suas mesas de dissecação propiciam um cenário perfeitamente grotesco, em que uma situação bizarra e horrorosa é contada com humor e irreverência: em primeiro lugar, a visão patética da vida humana e suas banhas que se assemelham a "enxúndia de galinha", as moscas pousando nos corpos, como se estivessem no lixo, a risada macabra de dentes brancos do negro, aliada a uma dança macabra (motivo recorrente do grotesco) dos esqueletos pendurados. Mas, ao longo da obra de Hermilo Borba Filho, nem sempre é possível rir dessas aulas de anatomia, principalmente quando os supostos "cadáveres" ainda estão bastante vivos, sendo torturados em calabouços e tendo seus corpos desnudos expostos no chão das cadeias, o que faz desses pisos sujos e sangrentos verdadeiras mesas de dissecação ou anexos do necrotério.

Sobre essas mesas de dissecação e a anatomia do corpo humano, Eliane Robert Moraes, em O corpo impossível (2002), faz uma análise do papel do corpo nas artes, especialmente quanto à fragmentação deste na estética moderna. A autora parte das várias versões literárias do episódio bíblico de Salomé e a decapitação de João Batista, concluindo com a constatação de que há, nessas versões, uma fusão desconcertante entre o erotismo e a perda de unidade do corpo. Essa união do erotismo e a perda de unidade antecipa praticamente toda a estética moderna europeia, a partir do fim do século XIX, com o corpo sendo cada vez mais apresentado de forma fragmentada e multifacetada. Dentre as ocorrências mais marcantes dessa fragmentação moderna, os quadros de Picasso são bons exemplos, o que, em Agá, é levado até as últimas consequências, em sua disseminação de Agás narradores em múltiplas 
perspectivas, além da nuance erótica presente na tortura e no sacrifício dos corpos desnudos dos prisioneiros.

Para desenvolver sua visão estética de fragmentação, erotismo e sacrifício, Moraes (2002) concentra-se, em boa parte, no movimento do surrealismo e, principalmente, no pensamento de Georges Bataille. E para se introduzir o surrealismo, normalmente se fala da influência de Emile Ducasse ou Lautréamont e suas imagens poéticas. Dessas imagens, a mais célebre é justamente a que fala do encontro de um guarda-chuva e uma máquina de costura: "Belo como...o encontro fortuito sobre uma mesa de dissecação de uma máquina de costura e um guarda-chuva!" (LAUTRÉAMONT, 2014, p. 252)

Moraes (2002) faz, então, um histórico de interpretações possíveis de imagem tão enigmática, citando que houve uma demora dos surrealistas em se engajarem numa explicação para tal comparação ou símile tão inusitado. Mas, segundo a autora, André Breton, por fim, analisa a imagem e sugere uma interpretação erótica e amorosa, em que o guarda-chuva simbolizaria o homem, enquanto que a máquina de costura seria a mulher e, por fim, a mesa de dissecação poderia ser vista como uma cama. Depois, Moraes (2002) apresenta uma outra interpretação, de Georges Bataille, que sugere um erotismo diferente da interpretação surrealista, ou seja, baseada na crença dele de que "o sentido último do erotismo é a morte" (MORAES, 2002, p. 53), e que envolve também uma nostalgia pelo ato sacrificial.

Embora Eliane Roberts leve em consideração tais possibilidades a mesa de dissecação como cama ou altar de sacrifício - ela prefere ver a mesa de dissecação pelo que ela é de fato é: um local e instrumento para o esquadrinhamento do corpo humano, seja em prol da ciência, seja como metáfora da crueldade humana configurada na ação dos 
extermínios em massa dos nazistas, o que, para a autora, tornaria as visões de Breton e Bataille até nostálgicas.

O que cremos é que, em Agá, todas essas interpretações são possíveis: ver o chão da prisão como cama ou pedra sacrificial, ou uma mesa de dissecação. Podemos, então, dizer que, nesse sentido último, o corpo do prisioneiro permanece, no caso do porão em Agá, em um limbo entre a vida e a morte que espreita o torturado. A cada sessão de tortura, o corpo do torturado se irmana, cada vez mais, aos cadáveres das aulas de anatomia, expondo não só a estrutura material da carne humana, sua fragilidade, mas - usando aqui uma expressão de Hanna Arendt revelando a própria anatomia da "banalidade do mal", em que funcionários subalternos - os torturadores e carcereiros - se encarregam de levar a cabo, de maneira sádica, o extermínio da vida, sem maiores reflexões sobre seus atos.

Uma outra maneira de se olhar para a questão da tortura em Agá, é que, quando observamos o rastro de destruição do corpo humano, nas sessões de tortura do prisioneiro, podemos ter a impressão de que tudo é realizado de maneira aleatória, mas, ao fim do martírio dele, é possível ver como se materializa, na linguagem, a imagem de seu corpo. Assim, quando o preso é despejado no chão da cela, o padre pode dizer:

Foi espancado mais cinco madrugadas seguidas, cada uma lhe tirando a vida aos poucos. Havia um propósito geográfico: primeiro ficou sem as orelhas, depois sem o bico dos peitos, em seguida com as mãos partidas, de outra com os testículos esmagados, por fim com as pernas quebradas (BORBA FILHO, 1974, p. 64).

Essa metodologia de destruição é ambígua no sentido de que isso tanto pode ser uma técnica do torturador quanto uma ação simbólica do 
narrador, naquilo em que este traduz o olhar sobre o torturado em linguagem. Esse "propósito geográfico" da tortura parece sugerir um procedimento padrão do olhar, da maneira como operava a pseudociência da fisiognomonia e também dos incipientes estudos de anatomia.

Jean-Jacques Courtine, em Decifrar o corpo (2013), apresenta o desenvolvimento de diversas maneiras de se "ler" o corpo humano, ou seja, em converter a imagem física do corpo em linguagem. E, para Courtine (2013), o primordial, nessa espécie de tradução, foi a classificação oriunda das ciências fisiognomônicas que, segundo ele, obedeciam a "um conjunto de exigências de legibilidade do corpo" (COURTINE, 2013, p. 47). Essas pseudociências foram usadas de várias maneiras ao longo do tempo, como na função de divinação do futuro em conjunto com a astrologia - ao analisar os traços estampados nos rostos ou nas mãos. Foi usada também nas tentativas de se prever o caráter ou inteligência, baseado na formação craniana, ou também foram base da incipiente ciência da medicina, que usava a fisiognomonia como maneira de perscrutar o doente. Ou seja, pelo exterior do paciente, o médico tentava, por analogia, diagnosticar o que se passava no interior do corpo humano.

Courtine (2013) ressalta que, apesar das intenções divinatórias da fisiognomonia, esta foi também participante, devido ao rigor de suas classificações, daquilo que ele chama de uma conversão do olhar sobre o corpo em discurso:

Estas fisiognomonias são submetidas a regras de escrita fixadas por uma longuíssima tradição, que atribuem uma forma linguística determinada a seus enunciados e que especificam o 
modo de encadeamento destes no texto, segundo o modelo de uma lista ordenada (COURTINE, 2013, p. 55).

Além dessa visada fisiognomônica, ordenada em lista, a anatomia também coopera na racionalização do olhar, devido a sua escrutinização do corpo, suas enumerações dos órgãos, dos caminhos das correntes sanguíneas, o que colabora na naturalização da imagem do homem, dissociando-o de sua aura sagrada ou misteriosa. E essas enumerações fisiognomônicas e anatômicas seguiam uma lógica estabelecida em longa tradição: de cima para baixo. Partia-se da parte superior do crânio, descendo analiticamente para o restante do corpo.

Portanto, da mesma forma como se dá na fisiognomonia, essa enumeração assemelha-se ao percurso escolhido pelos torturadores do prisioneiro, como na passagem citada mais acima, partindo do alto do corpo (as orelhas), seguindo descendentemente até as pernas. Mas, coincidentemente, o Agá padre e narrador é também um anatomista, um ex-estudante de medicina que percorre o corpo do torturado com interesse, traduzindo - através de seu diário - o corpo em linguagem, em literatura. Courtine (2013), ao finalizar sua análise das classificações e ordenações fisiognomônicas, propõe como poderiam ser feitas essas conversões simbólicas de corpo em linguagem, o que parece avalizar essas possibilidades interpretativas.

Em todos os casos, esta ordem tem funções múltiplas: primeiramente ela traduz o percurso do olhar do observador sobre o corpo humano, permite restituir-lhe o deslocamento. É neste sentido que este tipo de lista, que fornece às fisiognomonias seu plano, realiza a conversão de um olhar em discurso. Disso resulta uma tipografia ordenada do corpo, doravante representada sob a forma de um conjunto de lugares a percorrer em uma ordem determinada: o corpo visível entrou 
em um espaço abstrato de uma representação escrita (COURTINE, 2013, p. 74).

Vemos, então, nesse processo de conversão simbólica, vários agentes - os torturadores, o padre anatomista - que fazem o uso de objetos e de ambientes que temos visto até então, como a mesa de dissecação ou o sacrifício, as salas de anatomia, e as descrições ordenadas e metódicas que produzem uma imagem literária do corpo. Sobre essa última conversão, a da imagem literária, Courtine (2013) ainda nos dá mais uma importante possibilidade totalmente inserida na função da literatura: a memória. As longas e metódicas listas fisiognomônicas nada mais eram do que técnicas de memorização: "protocolos de observação destinados a regular e homogeneizar as percepções vindouras; são espécies de "modos de emprego" do olhar sobre o corpo" (COURTINE, 2013, p. 74). Essa "percepção vindoura" do corpo do torturado parece ser um bom uso para a imagem concebida pelo narrador de Eu, Padre, de não deixar cair no esquecimento o martírio dos que foram sacrificados, ou como diz Courtine, envolve a produção de uma "memória da alma" (COURTINE, 2013, p. 75).

Quanto à analogia com a figura de Cristo, a narrativa de Borba Filho dialoga continuamente com a Bíblia, não só em Agá, mas no restante de sua obra, sem esquecer, nessa ambiência de torturas e desmembramentos, da relação entre Cristo e diversos mitos, como os de Osíris, Orfeu e Dioniso, os quais sofreram despedaçamentos e sacrifícios, o que, para Brandão (1987), significa um rito de iniciação:

A cerimônia do despedaçamento simbólico do neófito ou mesmo iniciado, sempre relembrado no diasparagmós grego, quando se fazia em pedaços um animal, para recordar o "renascimento" de Dioniso [...] é um rito bem atestado em muitas culturas e sua finalidade última, já o frisamos, é fazer o 
neófito ou o iniciado renascer numa forma superior de existência. Assim o foi, entre outros, com Osíris, Dioniso e Orfeu (BRANDÃO 1987, p. 148).

Assim, mantendo em mente essas relações tão arquetípicas, em Agá, as alusões à analogia entre Cristo e o prisioneiro já começam por apresentar um carcereiro caridoso, de nome Mateus - um dos discípulos de Cristo -, que ajuda o padre, isso sem esquecer que Mateus é um dos personagens do Bumba-meu-boi, espetáculo nordestino tão pesquisado e apreciado por Hermilo Borba Filho. No Bumba-meu-boi, o boi também é sacrificado e morto ao final, o que mantém a narrativa nessa ambiência de sacrifício e morte de Cristo e de um prisioneiro. As semelhanças, então, vão se desenvolvendo gradativamente, em meio às constantes sessões de tortura no prisioneiro, aliadas às constantes celebrações da eucaristia por parte do padre

\footnotetext{
Mateus chegou neste instante com o café que servia antes de ser substituído pelo outro carcereiro e ficou à espera de que eu me entregasse ao Santo Sacrifício, saindo e voltando com o pão e o vinho para as celas de cada lado da minha (BORBA FILHO, 1974, p. 62).
}

Como se sabe, pela narrativa da Bíblia, a eucaristia advém do rito instituído por Cristo em sua última ceia com os apóstolos, pouco antes de ser preso e ser condenado à morte. Neste porão da ditadura em Agá, dividido pelo padre e outros presos, os eventos vão se desenrolando para pôr em paralelo constante os dois sacrifícios envolvidos: o de Cristo e o do preso político. Ambos se apresentam, por suas diversas causas e razões, para a humilhação e o martírio, o que torna o capítulo Eu, Padre praticamente uma santa ceia e Paixão, em que o sacrifício de ambos, do Cristo e do prisioneiro, se anunciam. 
Além dessa analogia entre os corpos dos dois torturados, do Cristo e do prisioneiro político, há outra perspectiva que nos aproxima do grotesco: a deformação do corpo de Cristo, nas artes pictóricas e no ensino da Igreja Católica, ao fim da idade média. Umberto Eco, em $A$ história da feiura (2015), parte de um comentário de Hegel, em sua Estética, em que o filósofo alemão levanta as dificuldades em se lidar com o corpo de Cristo da Paixão, seguindo uma concepção grega do belo. Essa questão nos põe em contato com a discussão sobre o rebaixamento do belo e do sublime, no pensamento de Mikhail Bakhtin sobre o grotesco, já que vários aspectos da beleza grega são abalados pela deformação do corpo de Cristo, pelo destaque dado às suas chagas sangrentas, que são fruto do martírio dos últimos dias de sua Paixão.

O ideal de beleza é, então, questionado, não porque não houvesse deformação na arte grega, mas por colocar no centro da arte o corpo sangrento de um Deus humanizado que não segue o padrão da beleza apropriado a uma divindade, mas que é, mesmo assim, um belo que se mistura à sujeira, à feiura e à falta de simetria. Essa imagem deformada de Cristo, segundo Eco (2015), pode ter vindo das profecias de Isaias, no Antigo Testamento, quando este anuncia a vinda do messias:

2 Porque foi subindo como renovo perante ele e como raiz de uma terra seca; não tinha aparência nem formosura; olhamolo, mas nenhuma beleza havia que nos agradasse.

3 Era desprezado e o mais rejeitado entre os homens; homem de dores e que sabe o que é padecer; e, como um de quem os homens escondem o rosto, era desprezado, e dele não fizemos caso.

4 Certamente, ele tomou sobre si as nossas enfermidades e as nossas dores levou sobre si; e nós o reputávamos por aflito, ferido de Deus e oprimido.

5 Mas ele foi traspassado pelas nossas transgressões e moído pelas nossas iniquidades; o castigo que nos traz a paz estava sobre ele, e pelas suas pisaduras fomos sarados. 
6 Todos nós andávamos desgarrados como ovelhas; cada um se desviava pelo caminho, mas o SENHOR fez cair sobre ele a iniquidade de nós todos.

7 Ele foi oprimido e humilhado, mas não abriu a boca; como cordeiro foi levado ao matadouro; e, como ovelha muda perante os seus tosquiadores, ele não abriu a boca (BÍBLIA, Isaías 53: 2-7).

Por essa perspectiva da "ovelha muda" e tosquiada, mais e mais pintores, como Giotto, Grünewald (Figura 1), entre outros, dedicaram-se a representar o Cristo em sua situação de humanidade e sofrimento na carne, o que não era costume até então, quando, no máximo, a cruz era usada simbolicamente como referência ao martírio.

Figura 1. Detalhe de Crucificação, de Mathias Grünewald (1515)

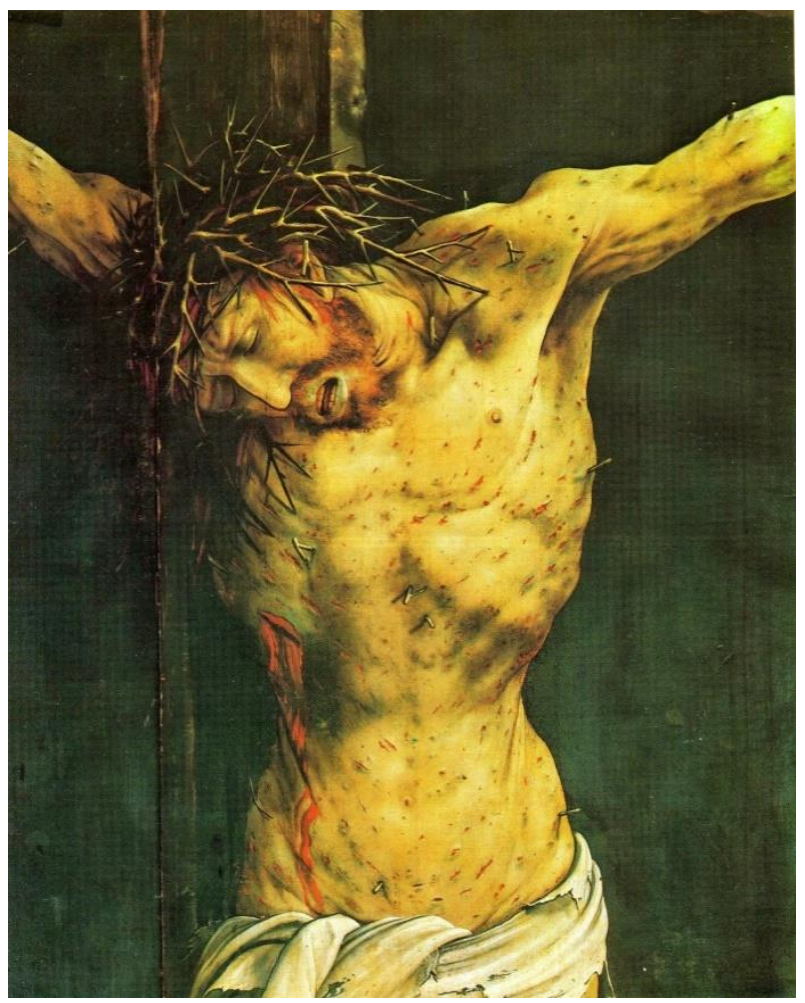

Fonte: ECO, 2015 
E ainda mantendo a semelhança entre Cristo e o prisioneiro em Agá, ambos não abrem a boca em seus interrogatórios. Na narrativa da Bíblia: "E, sendo acusado pelos principais sacerdotes e pelos anciãos, nada respondeu. Então, lhe perguntou Pilatos: não ouves quantas acusações te fazem? Jesus não respondeu nem uma palavra [...] (BÍBLIA, Mateus 27:12-14). Quanto ao romance Agá, o prisioneiro faz questão de demarcar silêncio diante dos inquisidores, após uma sessão de espancamentos, até pela importância que ele dava em ser fiel e não delatar os companheiros. Narra o padre: “Antes de falar, os lábios primeiro formaram os sons, a voz vindo depois, como num velho filme vitafone fora de sincronismo: Não falei... não falei...” (BORBA FILHO, 1974, p. 61). Na verdade, se olharmos, versículo por versículo dessa passagem, ela poderia ser trazida para o contexto político da época de Agá, quando muitos andavam "desgarrados como ovelhas”, mas alguns homens "de dores" souberam como padecer.

Aprofundando um pouco a figura de Cristo e seu corpo deformado, quanto a uma visão estrita da igreja católica, Jacques Gélis, em O corpo, a igreja e o sagrado (2012), nos relata que as concepções na representação de Jesus Cristo passam por uma transformação que se desenvolve desde os primeiros anos do cristianismo e desemboca no fim da Idade Média, quando Cristo foi de fato efetivado como fator central da pregação da Igreja. Assim, os textos e representações artísticas procuraram primeiro acentuar o que Gélis (2012) chama de os "traços da passagem" de Cristo na terra, dada a importância da encarnação e morte do Salvador. Se, no início, as representações eram mais suaves, muitas vezes se fixando nas cenas de manjedoura e nascimento do Messias, em momento posterior os sudários sangrentos 
tomaram relevância, por serem provas materiais da passagem do Cristo na terra. Esse desenvolvimento culmina no culto ao Cristo da paixão, o “culto dolorista” ou o culto ao "Homem das dores" (GÉLIS, 2012, p. 32), no que é bastante auxiliado pela arte e suas imagens.

\begin{abstract}
A imagem constituiu um instrumento essencial na difusão desse culto. Com o aparecimento da imprensa, inúmeras vinhetas piedosas vieram corroborar o discurso do clero e colocar à vista dos fiéis o corpo desfigurado e humilhado do Salvador. Veneração dos instrumentos da paixão, culto das cinco chagas, devoção especial à chaga do lado que levará à devoção ao Sagrado Coração de Jesus, mais tarde ao coração eucarístico e ao lagar místico; do século XIV ao século XVIII todo um novelo de crenças e de ritos implantou-se em torno do corpo sofredor de Cristo (GÉLIS, 2012, p. 26).
\end{abstract}

Ao esmiuçarmos esse percurso histórico da representação do corpo de Cristo, pretendemos, com isso, aprofundar a complexidade da analogia do corpo deste com o do prisioneiro torturado, tentando dar a dimensão e magnitude poéticas plasmadas na narrativa de Hermilo Borba Filho. Da mesma maneira como há esse, segundo Gélis (2012, p. 36), "aprofundamento anatômico e devocional" do corpo de Cristo, na história da representação do Salvador, assim também Hermilo Borba Filho tenta escrever um evangelho, com todos os detalhes de uma paixão, dos que perderam a vida nas masmorras de ditaduras, anunciando, pelo menos na forma de um romance, que o sacrifício - se foi em vão, ou não - pelo menos foi aposto em um memorial. Interessantemente, nos relatos mais fantasiosos e apócrifos da Paixão de Cristo, assim como nas pinturas europeias, Jesus é contextualizado em situações não respaldadas pelas Escrituras, mas que, de certa forma, 
aproximam esses relatos e imagem de Cristo à "Paixão" do prisioneiro político:

Esculturas e pinturas de Cristo coberto de equimoses e chagas sangrentas, entravado por ferros, encadeado numa cela estreita são frequentes nos santuários da Baviera e da Suábia, e, em 1750, esta sequência aparece no texto da Paixão de Oberammergau. Algumas imagens do Salvador no calabouço - Kerkerheiland - evocam as salas de tortura e os métodos de uma justiça cruel, como podemos ver nos documentos dos séculos XVI e XVII. (GÉLIS, 2012, p. 34).

Dessa forma, nessa cela comum, sofrendo desfigurações comuns, a imagem de Cristo e a do prisioneiro vão cada vez mais se amalgamando: a dor de Cristo o humaniza, da mesma forma que beatifica o prisioneiro. Com o desenrolar das ações, dá-se a passagem para mais uma espécie de ritual, saindo do culto ao corpo dorido da Paixão para o da eucaristia ou do corpo de Cristo transubstanciado no pão. Mas antes disso, o padre narra a via-crúcis final do prisioneiro, em suas últimas sessões de tortura:

Ajoelhei-me e fiquei monologando, Deus não atendia meu chamado, a exaustão levou-me a recostar a cabeça na cama dura, não sei por que eu só via um regato com seixos brancos no fundo, um regato infantil, onde não saberia dizer, da minha lassidão fui arrancado pelo ruído de ferro contra ferro, o Homem foi atirado para o cimento, quase irreconhecível, o sangue pingava de vários lugares, estava nu. Fiquei olhando para aquela chaga, uma posta de carne, um camorim de guelras abertas, um camarão retorcido (BORBA FILHO, 1974, p. 64) (grifo nosso)

É quase que inegável, com esse desfecho para o martírio do prisioneiro, a fusão que Hermilo Borba Filho realiza do corpo dos dois mártires, ao grafar o torturado como "Homem", capitalizado, à maneira que Cristo é referenciado nas escrituras, ou, no mínimo, associa o 
sofrimento do prisioneiro com o suplício de todos que sofreram perseguição e tortura na humanidade. Além disso, as metáforas grotescas se fazem presentes para caracterizar o prisioneiro: a chaga que rebaixa o ser humano a um estágio inanimado de "uma posta de carne", reduzindo-o a "um camorim de guelras abertas, um camarão retorcido". Por fim, a nudez que, segundo Bataille (2013), no relacionamento erótico, é uma espécie de simulacro da imolação, e que também chama a atenção de Jacques Gélis, quando este fala dos "sofrimentos ocultos" de Cristo, também usados para sensibilizar a fé dos fiéis:

A língua traspassada depois da coroação de espinhos, a reclusão no calabouço depois da flagelação, a chaga no ombro provocada pelo carregar a cruz, as pernas interiores depois das humilhações sofridas, em particular o desnudamento, constituem temas desenvolvidos pelos textos apócrifos e pela ilustração (GÉLIS, 2012, p. 33).

Portanto, com a aproximação da morte do prisioneiro, todas as sugestões de analogias e metáforas com o sacrifício de Cristo encaminham-se para a própria transubstanciação do corpo deste, mas, de maneira ambígua, essa transubstanciação não parece acontecer no pão que o padre ministra aos presos, mas no próprio corpo do prisioneiro:

No começo do sexto dia senti que ia morrer pelo silvo da sua respiração, pela palidez que se estendia por seu corpo martirizado. Aprestei-me para ajudá-lo com um arremedo de cerimonial, estávamos numa catacumba, voltávamos no tempo. Quando me ajoelhei ao lado da cama sua mão procurou a minha, tentando apertá-la a pressão relaxando aos poucos, todo ele indo embora. Acho que adivinhei o minuto exato em que se desprendia. Curvei-me beijei-lhe a 
mão, ouvi a minha voz dizendo-lhe: Isto é meu corpo... (BORBA FILHO, 1974, p. 64).

Por fim, e ironicamente, numa espécie de Gênesis às avessas, o homem é destruído justamente no mesmo sexto dia em que homem e mulher são criados no livro bíblico. E destruído metodicamente pela tortura. E da mesma forma como acontece, em outros momentos da literatura de Borba Filho, e no romance Agá, a narrativa se descola de uma postura puramente realista, assumindo uma ambiência onírica ou mágica: padre e prisioneiro se deslocam no tempo, para uma catacumba qualquer, repetindo um ritual de martírio convertido para a linguagem simbólica da literatura. A catacumba, também, não deixa de remeter o romance de Hermilo Borba Filho aos princípios de qualquer reflexão etimológica sobre o grotesco: uma arte que se realiza na gruta, nessa espécie de ventre escuro de onde nasce a bela poética do autor pernambucano. E nessa poética de Hermilo Borba Filho, sua obra torna-se - especialmente no romance Agá - um verdadeiro memorial da tortura e do assassinato dos que se rebelaram contra o poder ditatorial do regime militar, do sacrifício dos que não desistiram da luta pela liberdade do Homem, essa liberdade sem preço que talvez seja o tema central da literatura do pernambucano Hermilo Borba Filho, o que faz de sua obra algo ainda tão atual.

\section{Referências}

BAKHTIN, M. A cultura popular na idade média e no renascimento: o contexto de François Rabelais. Tradução de Yara Frateschi Vieira. São Paulo: Hucitec, 2013. 
BATAILLE, G. O erotismo. Trad. Fernando Scheibe. Belo Horizonte: Autêntica, 2013.

BORBA FILHO, H. A porteira do Mundo. 2. ed. Porto Alegre: Mercado Aberto, 1994.

Margem das lembranças. 2. ed. Porto Alegre: Mercado Aberto, 1993.

. Agá. Rio de Janeiro: Civilização Brasileira, 1974.

Deus no pasto. Rio de Janeiro: Civilização Brasileira, 1972.

O cavalo da noite. Rio de Janeiro: Civilização Brasileira, 1968

BÍBLIA. Português. Bíblia sagrada: contendo o antigo e o novo testamento. Tradução de João Ferreira de Almeida. Rio de Janeiro: Sociedade Bíblica do Brasil, 1966.

BOSCH. Abril Coleções. Trad. Simone Novaes Esmanhotto. São Paulo: Abril, 2001. (Coleção Grandes Mestres; v. 19).

BOSING, W.; BOSCH, H. Hieronymus Bosch, cerca de $145^{\circ}$ a 1516: entre o céu e o inferno. Köln: Taschen. 2001.

BRANDÃO, Junito de Souza. Mitologia grega. Petrópolis: Vozes, 1987. v. 2.

COURTINE, J.-J. Decifrar o corpo: pensar com Foucault. Trad. Francisco Morás. Petrópolis, RJ: Vozes, 2013.

ECO, Umberto. História da feiura. Trad. Eliana Aguiar. Rio de Janeiro: Record, 2015.

GÉLIS, Jacques. O corpo, a igreja e o sagrado. In: CORBIN, A.; COURTINE, J. J.; VIGARELLO, G. (Org.). História do corpo: da renascença às luzes. Petrópolis: Vozes, 2012. v. 1.

LAUTRÉAMONT, Conde de. Os Cantos de Maldoror, poesias, cartas (obra completa). Trad. Prefácio de notas Claudio Willer. 2.ed. rev. e ampl. São Paulo: Iluminuras, 2008. 2014.

LIMA, S. D. Gênese de uma poética da transtextualidade: apresentação do discurso hermiliano. João Pessoa: Ed. Universitária da UFPB, 1993.

MORAES, E. R. O corpo impossível. São Paulo: Iluminuras, 2002. 


\section{LISTA DE ILUSTRAÇÕES}

Figura 1 - Detalhe de Crucificação, de Mathias Grünewald (1515) (Fonte: ECO, Umberto. História da feiura. Trad. Eliana Aguiar. Rio de Janeiro: Record, 2015).

Recebido em 30/o6/2017

Aprovado em 09/10/2017. 